\title{
First report of Scutariella japonica (Matjašič, 1990), a temnocephalid epibiont from South-East Asia, found on introduced ornamental freshwater shrimp in European waters
}

\author{
Rafał Maciaszek ${ }^{1, *}$, Wiesław Świderek ${ }^{1}$, Anita Kaliszewicz ${ }^{2}$, Kamil Karaban ${ }^{2}$ and Bartłomiej Szpakowski ${ }^{3}$ \\ ${ }^{1}$ Department of Animal Genetics and Conservation, Institute of Animal Sciences, Warsaw University of Life Sciences, ul. Ciszewskiego \\ 8, 02-786 Warsaw, Poland \\ ${ }^{2}$ Institute of Biological Sciences, Cardinal Stefan Wyszynski University in Warsaw, Wóycickiego 1/3, 01-938 Warsaw, Poland \\ ${ }^{3}$ Department of Aquatic Bioengineering and Aquaculture, Faculty of Food Sciences and Fisheries, West Pomeranian University \\ of Technology, ul. Kazimierza Królewicza 4, 70-001, Szczecin, Poland
}

Received: 22 February 2021 / Accepted: 22 April 2021

\begin{abstract}
This contribution presents the first record of ornamental shrimp epibiont, Scutariella japonica (Platyhelminthes: Temnocephalida) in European waters. The species lives on freshwater Atyidae shrimp from temperate, subtropical and tropical zones of South-East Asia. In total, 120 individuals of Neocaridina davidi shrimp were caught in thermally polluted canal of Oder river, near the city of Gryfino, in the northwest part of Poland. In that group, 5.83\% were infected with scutariellids. Among shrimp, females were mostly infected (85.71\%). Since ornamental shrimp released into thermally polluted water bodies have been also noticed in surrounding waters of natural temperature regime in Europe, $S$. japonica may spread further following potential expansion of the Neocaridina shrimp in Oder river. It is possible that other crustaceans, both native and alien which are present at this location, may also become vectors of this epibiont.
\end{abstract}

Keywords: Alien species / ornamental pet trade / Scutariellidae / Vorticellidae / Neocaridina davidi / thermally polluted waters

Résumé - Premier signalement de Scutariella japonica (Matjašič, 1990), un épibionte temnocéphalide d'Asie du Sud-Est, trouvé sur des crevettes d'eau douce ornementales introduites dans les eaux européennes. Cette contribution présente le premier signalement de l'épibionte des crevettes d'ornement, Scutariella japonica (Platyhelminthes: Temnocephalida) dans les eaux européennes. L'espèce vit sur des crevettes Atyidae d'eau douce provenant des zones tempérées, subtropicales et tropicales de l'Asie du Sud-Est. Au total, 120 individus de crevettes Neocaridina davidi ont été capturés dans un canal thermiquement pollué de la rivière Oder, près de la ville de Gryfino, dans le nord-ouest de la Pologne. Dans ce groupe, 5,83\% étaient infectés par des scutariellidés. Parmi les crevettes, les femelles étaient principalement infectées $(85,71 \%)$. Comme les crevettes d'ornement relâchées dans des plans d'eau thermiquement pollués ont également été remarquées dans les eaux environnantes au régime de température naturel en Europe, $S$. japonica pourrait se propager davantage suite à l'expansion potentielle des crevettes Neocaridina dans le fleuve Oder. Il est possible que d'autres crustacés, à la fois indigènes et exotiques, présents à cet endroit, deviennent également des vecteurs de cet épibionte.

Mots clés : Espèces exotiques / commerce des animaux d'ornement / Scutariellidae / Vorticellidae / Neocaridina davidi / eaux thermiquement polluées

\footnotetext{
*Corresponding author: rafal_maciaszek@sggw.edu.pl
} 


\section{Introduction}

Releases of non-indigenous crustaceans into natural water ecosystems are known to have major negative effects on the native species and food chains (Twardochleb et al., 2013; Šidagyte et al., 2017; Zhang et al., 2019). However, it can get even worse if these species are accompanied by other organisms, such as epibionts, often accidentally introduced to European waters. Some of them, like Temnosewellia minor (Haswell, 1887) or Aphanomyces astaci (Schikora, 1906) can be transmitted to other crustaceans what may have an impact on natural biodiversity (Diéguez-Uribeondo and Söderhäll, 1993; Chiesa et al., 2015)).

Ornamental freshwater shrimp Neocaridina davidi (Bouvier, 1904) of the family Atyidae, belongs to the most common crustaceans in global aquarium pet market. The shrimp is characterised by widespread variety of colour and quickly became an interest of aquarists. This has led to mass production of these crustaceans in aquaculture ponds mainly in Taiwan (Maciaszek et al., 2018). As a result of intentional or unintentional releases from pet traders, $N$. davidi representatives are present also in waters outside its native range. Originally occurred in South-East Asia (Klotz et al., 2013), $N$. davidi representatives have colonised new locations in temperate, subtropical and tropical zones around the world as an alien species (Englund and Cai, 1999; Mitsugi et al., 2018; Levitt-Barmats et al., 2019; Onuki, 2021). Effects of their uncontrolled releases have been described in European natural and commercially induced thermal waterbodies in Germany, Poland and Hungary (Klotz et al., 2013; Jabłońska et al., 2018a; Weiperth et al., 2019). In Hungary, shrimp were even reported to be found in colder waters, more specific to water temperature regime of Central Europe (Weiperth et al., 2019).

Unfortunately, $N$. davidi is known to be a host of at least two specific epibionts, including temnocephalid, Scutariella japonica (syn. Cardinicola japonica) (Matjašič, 1990) and branchiobdellidan, Holtodrilus truncatus (Liang, 1963). Both species were observed coexisting in host gill chambers in native populations of the shrimp in Taiwan (Ohtaka et al., 2015). They were accidentally introduced in Japan, with wildcaught shrimp imported for fishing purposes (Niwa and Ohtaka, 2006). It is likely that they are also widespread in aquaculture ponds or aquarium hobby, as they can be found with imported ornamental shrimp and at least one of them, $S$. japonica has been already confirmed in both types of shrimp farming (Klotz et al., 2013; Maciaszek et al., 2018; Maciaszek et al., 2020). Aquaculture ponds create favourable conditions for the development of shrimp epibionts including representatives of Vorticellidae, mainly because of the high levels of organic matter in water and plankton, which could be recognizable as an additional source of their food. It is the main reason, $S$. japonica adults are often observed hunting for food at rostral area of shrimps. The species can be also found attached to pereiopods or pleopods. These locations belong to suitable for $S$. japonica, thanks to water moves regularly delivering organic matter (Maciaszek et al., 2018). Similar location preferences can be observed in vorticellids, however, their colonies are found also in other body parts (Patoka et al., 2016a; Liao et al., 2018; Maciaszek et al., 2018). Scutariella japonica is known to spend most of its life in host gills where is lays eggs (Matjašič, 1990). Presence of this epibiont on shrimp in most cases does not impact host health as long as it occurs in relatively small numbers. Mass quantities of $S$. japonica specimens (as well as vorticellids) can be dangerous especially for moulting crustaceans. Shrimp may not survive this process due to stress caused by the activity of the epibiont as well as host weakness can be used as a potential gate for infections of other organisms (Liao et al., 2018; Maciaszek et al., 2018).

In Europe, several genera of Scutariellidae are known to be epibionts of freshwater crustaceans. Among them, only representatives of genus Scutariella have been reported from shrimp of the family Atyidae (Matjašič, 1990). Most species can be found in caves, where they often live on endemic shrimp. However, one species, Scutariella didactyla (Mrázek, 1907) is the only European representative of the genus found in branchial cavity of Atyaephyra vladoi (Jabłońska et al., 2018b) occurring in Skadarsko lake and its tributaries (Matjašič, 1990; Jabłońska et al., 2018b).

If introduced, $S$. japonica as a new alien epibiont species may become a possible threat to European native species, potential hosts as well as their epibionts, including other epibiotic platyhelminths like dalyellid Varsoviella kozminskii (Giesztor and Wiszniewski, 1947), living on gammarids. As scutariellids are known not only from shrimp, it is likely that in some cases, they could be transmitted also by other crustaceans, including crayfish (Matjašič, 1990; Ohtaka et al., 2012). The spread can be intensified by thermal pollution of waters or climate change, since warmer waters create more favourable conditions for S. japonica (Maciaszek et al., 2018).

In this study, we provide first report on the occurrence of epibiotic $S$. japonica in European thermally polluted waterbodies.

\section{Material and methods}

\subsection{Locality}

Sampling site was located at thermally polluted canal $\left(53.2101^{\circ} \mathrm{N} ; 14.4638^{\circ} \mathrm{E}\right)$ situated south of Gryfino in northwest Poland, ca. $7 \mathrm{~km}$ from the border with Germany (Fig. 1), which is a part of Dolna Odra Power Plant cooling system and therefore contains heated waters. According to measurements provided by Fisheries Research Station of West Pomeranian University of Technology, average year water temperature in this location is $20.9{ }^{\circ} \mathrm{C}$ while the minimum and maximum are $7.5^{\circ} \mathrm{C}$ and $34.2^{\circ} \mathrm{C}$. The canal is known for the presence of both native and alien species. The latter are represented mainly by fishes such as Cyprinus carpio (Linnaeus, 1758), Lepomis gibbosus (Linnaeus, 1758), Neogobius melanostomus (Pallas, 1811) and invertebrates like crayfish Faxonius limosus (Rafinesque, 1817) or bivalve Sinanodonta woodiana (Lea, 1834). Aquarium-related species have been also noticed. Estabilished populations of another bivalve Corbicula fluminea (Müller, 1774), shrimp N. davidi and fish Piaractus brachypomus (Cuvier, 1818) have been found being present in this location for at least 10 years. Preying on shrimp in this site was observed in most fish species, mainly L. gibbosus and N. melanostomus. 


\subsection{Animals collection, epibiont detection and observation}

In total, 120 adult individuals of $N$. davidi (min. $1.5 \mathrm{~cm}$ length) including 85 females and 35 males, were collected from the Ciepły Canal of Dolna Odra Power Plant. Shrimp were caught using long-handled dip net and flashlight at the waterside controlled by Fisheries Research Station of West Pomeranian University of Technology. They were collected from mostly rocky or sand substrata and depth not exceeding

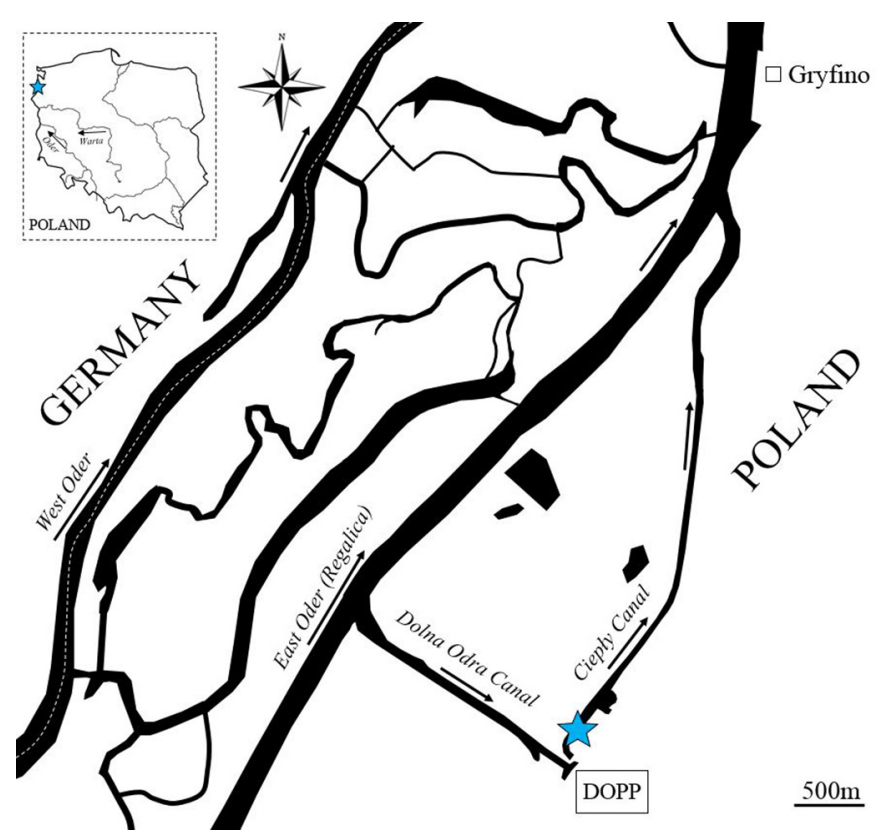

Fig. 1. Location of sampling site (blue asterix) on the map of Poland and Ciepły Canal of Dolna Odra Power Plant (DOPP).
$0.5 \mathrm{~m}$. Survey carried out on March 10, 2018 was made during nighttime and lasted ca. 120 minutes. Collected shrimp were observed for selected epibionts (Annellida, Ciliata, Platyhelminthes) presence under digital microscope Keyence VHX7000 at 500-1500x magnification. Among epibionts, presence of vorticellids was used only as an indicator of organic matter quantity in the water, which can impact presence of scutariellids (Maciaszek et al., 2018; Kondrateva et al., 2019). Isolated epibionts were examined for morphological features using available literature (Matjašič, 1990; Ahn and Min, 2016).

\section{Results}

Total of six adult representatives and 15 eggs of scutariellids were found in gills area of seven infected shrimp $(5.83 \%)$ among examined group of $120 \mathrm{~N}$. davidi shrimp (Tab. 1). Despite difference in sex ratio in infected shrimp, females were more preferred $(85.71 \%)$ than males $(14.29 \%)$. Vorticellids were found in 99 shrimp $(82.5 \%)$, out of which $69.07 \%$ were females and $30.93 \%$ were males. They were mostly attached to shrimp pleopods and pereiopods. In contrast to males, females were hosts for more vorticellid specimens. Individuals free of examined epibionts (both vorticellids and scutariellids) constituted $17.5 \%$ of the group. In 10 shrimp $(8.33 \%)$ melanized damages in gills were observed. Detailed data on selected epibionts presence was presented in Table 1.

All scutariellids were identified as $S$. japonica (Matjašič, 1990) (Fig. 2). Collected individuals were characterised by following features: body transparent white, reaching $2.1 \mathrm{~mm}$ when not extended (similar size was noticed after preservation in $96 \%$ ethyl alcohol); two tentacles, each with cylindrical base and independent sucker; two eyes present, well developed; pharyngeal glands absent or not well developed; two testes and separated vitelline glands located on each side of the body; adhesive attachment organ, single, horseshoe-shaped (Fig. 3).

Table 1. Occurrence of examined epibionts (S. japonica, Vorticellidae) in $N$. davidi shrimp collected from the thermally polluted canal of Oder River.

\begin{tabular}{|c|c|c|c|c|c|}
\hline \multicolumn{2}{|c|}{ N. davidi } & \multicolumn{3}{|c|}{ Scutariellidae } & \multirow{2}{*}{$\begin{array}{l}\text { Vorticellidae } \\
\text { Confirmed presence } \\
\text { (live individuals)* }^{*}\end{array}$} \\
\hline No. & Sex & Adults quantity & Eggs quantity & $\begin{array}{l}\text { Confirmed activity } \\
\text { (damages in gills) }\end{array}$ & \\
\hline 1 & $\mathrm{~F}$ & 2 & 8 & + & ++ \\
\hline 2 & $\mathrm{~F}$ & 1 & 3 & + & ++ \\
\hline 3 & $\mathrm{~F}$ & 1 & 2 & + & ++ \\
\hline 4 & M & 1 & & & \\
\hline 5 & $\mathrm{~F}$ & 1 & & & \\
\hline 6 & $\mathrm{~F}$ & & 1 & + & ++ \\
\hline 7 & $\mathrm{~F}$ & & 1 & + & + \\
\hline \multirow[t]{4}{*}{ 8-13 } & F (3) & & & + & ++ \\
\hline & M (2) & & & + & + \\
\hline & F (32) & & & & ++ \\
\hline & $\mathrm{F}(25)$ & & & & + \\
\hline \multirow[t]{3}{*}{$14-120$} & M (27) & & & & + \\
\hline & F (16) & & & & \\
\hline & M (5) & & & & \\
\hline
\end{tabular}

*Higher quantity (hundreds) of specimens marked with "++". 


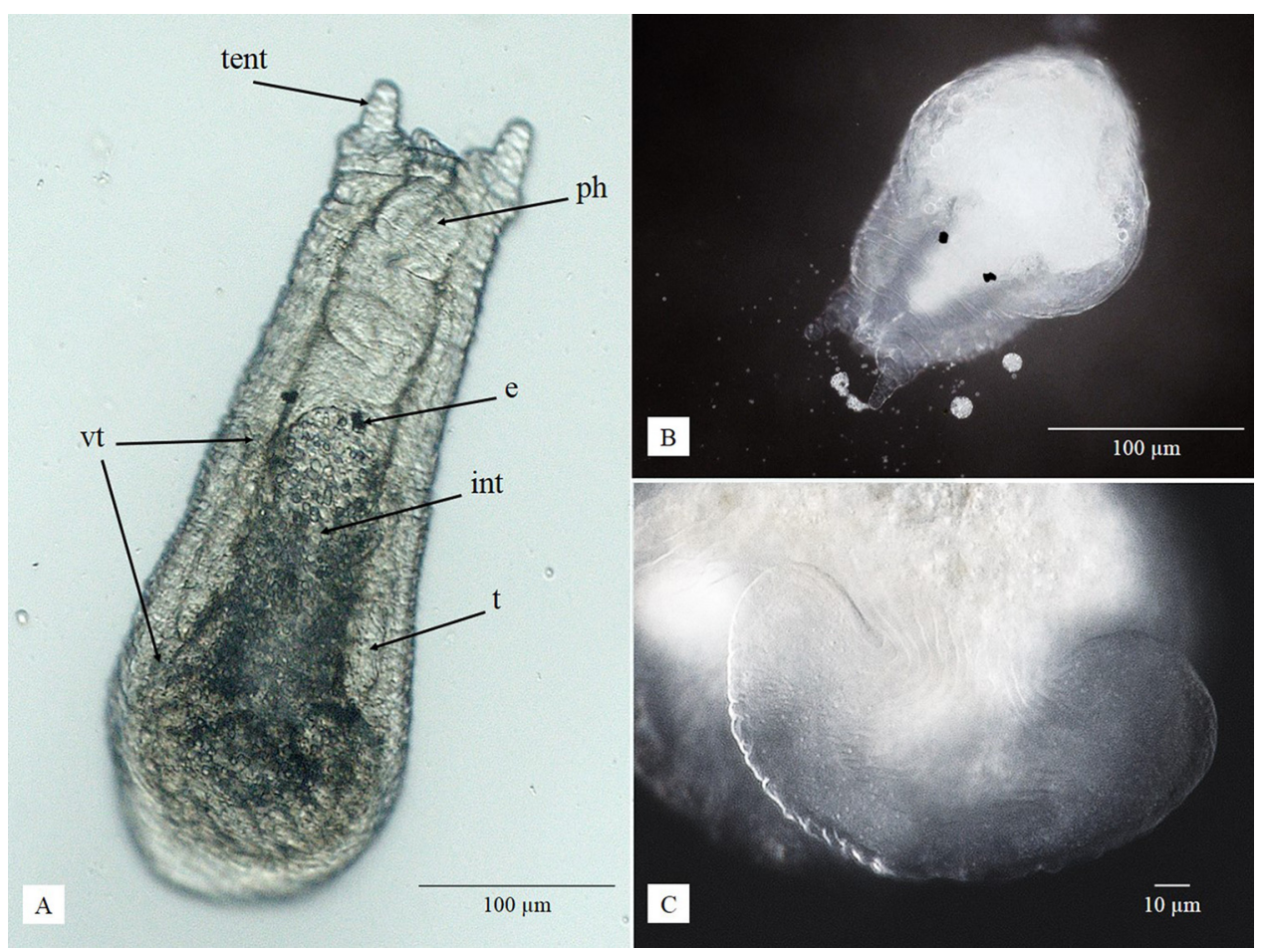

Fig. 2. Adult representative of Scutariella japonica collected from Oder River: live specimen (A, B); horseshoe-shaped adhesive attachment organ $(\mathrm{C})$; e - eye, int - intestine filled up with the shrimp's hemolymph, ph - pharynx, $\mathrm{t}-$ testis, tent - tentacle, vt - vitelline glands.

\section{Discussion}

We provide first documented data on the occurrence of S. japonica in European waters, more precisely, thermally polluted canal of Dolna Odra Power Plant in Poland. The species can be easily distinguished from most European members of the genus by presence of the eyes and simultaneously occurrence of characteristic, horseshoe-shaped adhesive attachment organ which is heart-shaped in S. didactyla (Matjašič, 1990). Among other known representatives with developed eyes, $S$. japonica is distinct from $S$. indica (Annendale, 1912) by presence of two, instead of four testes (Matjašič, 1990), and unlike S. sinensis (Wang and Chen, 2018) it has not well developed pharyngeal glands (Chen et al., 2018).

Among examined $N$. davidi shrimp, occurrence of S. japonica in gill chambers and vorticellids in external body parts reflects most suitable body parts for these epibionts (Matjašič, 1990; Ohtaka et al., 2012; Maciaszek et al., 2018). In comparison to most studies which had been carried out on Asian populations (Niwa and Ohtaka, 2006; Ohtaka et al., 2012; Ohtaka et al., 2015), including those from aquaculture ponds (Maciaszek et al., 2018), much smaller prevalence of $S$. japonica on $N$. davidi was found in our study. It may suggest that the habitat conditions of Ciepły Canal are not proper for the species, although vorticellids quantity implies optimal levels of organic matter in the water (Maciaszek et al., 2018). On the other hand, it could be an effect of increased predation on shrimp infected by this epibiont due to possible host stress (Liao et al., 2018; Maciaszek et al., 2018). In most cases $S$. japonica adults or eggs were observed at once with melanized damages in host gills, except two hosts in which only adults were found, possibly recently invaded.
Simultaneous occurrence of scutariellids and the damages implies that activity of the epibionts somehow leads to partial melanization of gills, however it has not been earlier reported (Ohtaka et al., 2012). Potential reinvasion on the same, previously moulted shrimp should not be excluded, especially that in both cases, hosts were also free of vorticellids or scutariellid eggs, which can be removed with shrimp moult (Klotz et al., 2013). Among infected shrimp, females more likely presented damages in the cuticle, suggesting that the activity of S. japonica might be higher on them than on males, what is supported also by the presence of eggs only on females. This is most likely a result of more surface available to attach on females which grow bigger than males (Vazquez et al., 2017), what can also be observed in quantity of vorticellids, which was also lower in males. On the other hand, females are often characterised with body covered by more intense pigmentation (Tomas et al., 2019), which probably creates favourable shelter conditions for scutariellids hiding in host gill chambers.

Occurrence of $S$. japonica in Ciepły Canal of Oder river is most likely a result of accidental introduction with ornamental shrimp, $N$. davidi, that have been observed in the site since 2003 (Jabłońska et al., 2018a). However, based on the quantity of alien species in the area, possible origin like separate releases or numerous introductions of ornamental shrimp should not be excluded. Therefore, release of and first observation of $N$. davidi on this location may not be connected. As Jabłońska et al. (2018a) proposed, introduction of shrimp, including infected ones, was apparently an action of irresponsible owner and originated from aquarium culture. Neocaridina davidi from Ciepły Canal presents similar features with specimens occurring in aquaria as well as in 


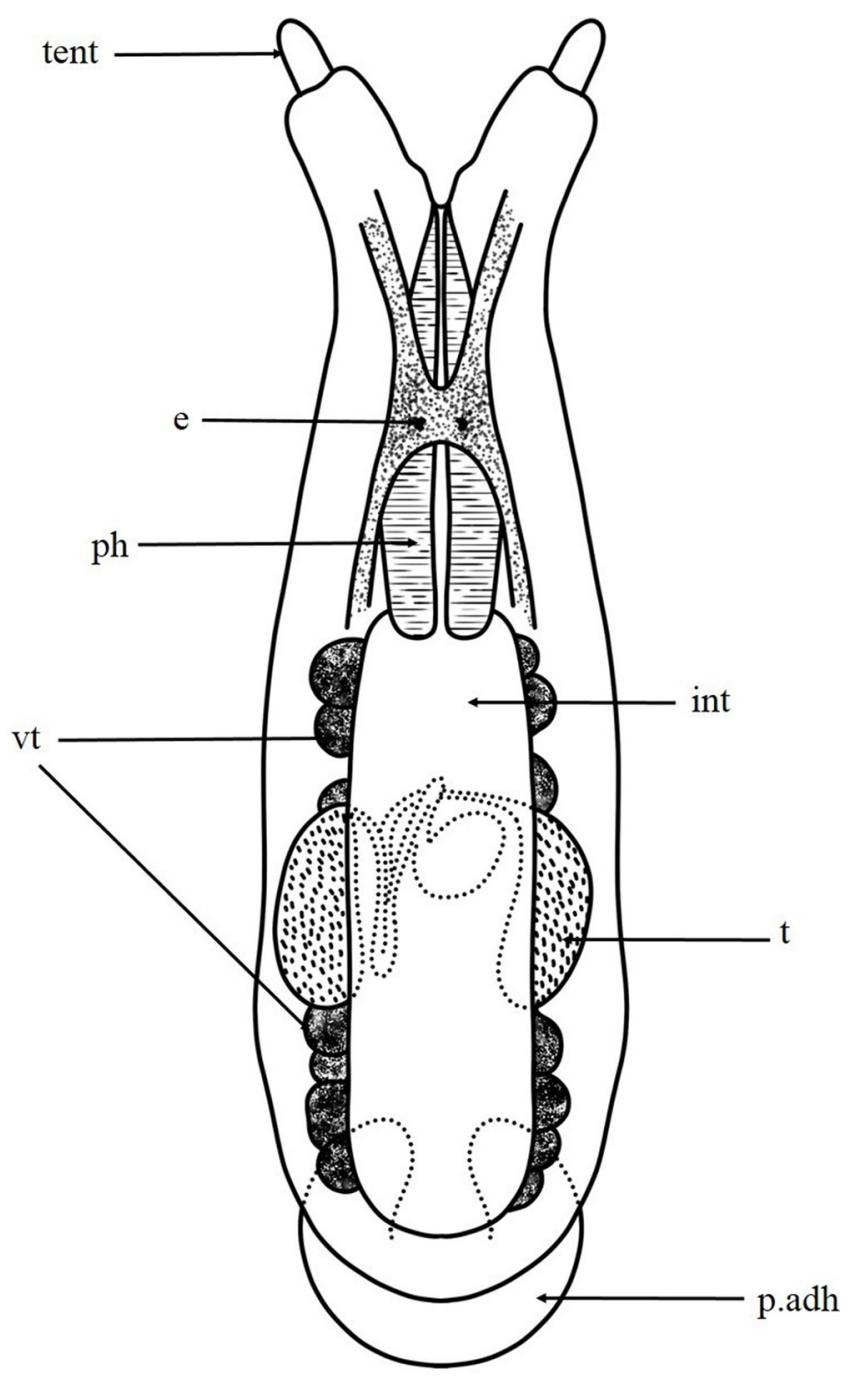

Fig. 3. Dorsal view of collected Scutariella japonica based on Matjašič (1990): e - eye, int - intestine, p.adh - posterior adhesive organ, $\mathrm{ph}-$ pharynx, $\mathrm{t}-$ testis, tent - tentacle, $\mathrm{vt}-$ vitelline glands.

the wild in Taiwan. This may confirm origin of examined $S$. japonica, which is probably the same species as observed in European aquaria, Taiwanese seminatural farms and natural waterbodies (Ohtaka et al., 2015; Maciaszek et al., 2018). If so, it is expected that vorticellids found in $N$. davidi, might also be introduced aliens (Patoka et al., 2016a). However, this would not be a surprise, since until now there are no control methods introduced on large scale. Unwanted hitchhikers are still present in imported shrimp from Asia as well as in the European pet trade (Patoka et al., 2016a; Patoka et al., 2016b; Maciaszek et al., 2018).

Further spread of $S$. japonica in European waters and its possible transmission to other crustaceans is potentially dangerous to native species. Presence of $S$. japonica may affect growth and reproduction of host, by causing stress and problems with moulting and health as well (Matjašič, 1990; Maciaszek et al., 2018). As scutariellids are known to be epibionts of freshwater shrimp, also can be transmitted to other crustaceans such as crayfish, these can be their potential vectors. Unfortunately, all these crustaceans can be found in Ciepły Canal. Although $N$. davidi has not yet been reported as an escaper from the location, it is possible that the shrimp has already colonised surrounding areas, following other aliens (Łabęcka and Domagała, 2018; Weiperth et al., 2019) supporting spread of $S$. japonica. Moreover, Oder river is located in west part of geographic range of Atyaephyra desmarestii (Millet, 1831), the most likely European host for S. japonica. In contrast to Atyaephyra vladoi (Jabłońska et al., 2018b) from the ancient Skadar Lake system, A. desmarestii is not known for the presence of $S$. didactyla, the only known European scutariellid found in shrimp living in surface waters (Matjašič, 1990; Pešić et al., 2018). If infected, the shrimp could become a potential vector of $S$. japonica and transmit this epibiont to south-west parts of the continent, finally reaching sites of other endemic shrimp and in some cases, their native scutariellids. However, invasion of this epibiont would not impact shrimp populations living in brackish water, which is deadly for scutariellids (Gottstein and Kerovec, 2002; Niwa and Ohtaka, 2006). Luckily, possible transmission to crayfish may be limited by other epibionts, including European branchiobdellidans, which in contrast to $H$. truncatus, are not harmoniously coexisting with scutariellids, as they prey on them (Gelder, 1999; Ohtaka et al., 2012). In Polish waters, $S$. japonica may eventually compete with exemplary $V$. kozminskii in gills of gammarids. Although possible cohabitation of two epibiotic platyhelminths (scutariellids) is known from Ceylon (Matjašič, 1990), impact of new invader on European species both native as well as above mentioned aliens remains unknown.

To sum up, the occurrence of S. japonica in Ciepły Canal of Odra river creates opportunities for its further spread in Europe. This may be supported by transmission to native as well as nonindigenous crustaceans and may have negative impact on native species.

We, therefore, urge for more control over this epibiont, using preventive methods that need to be yet developed, such as proper quarantine for ornamental shrimp (at least two-three weeks in aquarium allowing observation of all specimens and removing moults) and baths in saline solutions (30 seconds bath in $40 \mathrm{~g}$ sodium chloride per 11 of aquarium water) (Maciaszek, 2016), which are still rarely used in aquarium hobby. Population of $N$. davidi should be covered by monitoring and if possible, wiped out from the site. We recommend catching shrimp and their epibionts for experimental purposes or moving them to educational aquariums, for promotion of responsible aquarium hobby.

\section{References}

Ahn DH, Min GS. 2016. First report of the branchiobdellidan Holtodrilus truncatus (Annelida: Clitellata) found on the freshwater atyid shrimp Neocaridina sp. from Korea. $J$ Species Res 5: 459-462.

Chen L, Feng WT, Lin YT, Lu SY, Wang AT. 2018. A new species of genus Scutariella (Rhabdocoela: Scutariellidae) and molecular phylogenetic analysis. Sichuan Dong $W u$ 37: 74-81.

Chiesa S, Scalici M, Lucentini L, Marzano FN. 2015. Molecular identification of an alien temnocephalan crayfish parasite in Italian freshwaters. Aquat Invasions 10: 2. 
Diéguez-Uribeondo J, Söderhäll K. 1993. Procambarus clarkii Girard as a vector for the crayfish plague fungus, Aphanomyces astaci Schikora. Aquac Res 24: 761-765.

Englund RA, Cai Y. 1999. The occurrence and description of Neocaridina denticulata sinensis (Kemp, 1918) (Crustacea: Decapoda: Atyidae), a new introduction to the Hawaiian Islands. Occas Pap Bernice P Bishop Mus 58: 58-65.

Gelder SR. 1999. Zoogeography of branchiobdellidans (Annelida) and temnocephalidans (Platyhelminthes) ectosymbiotic on freshwater crustaceans, and their reactions to one another in vitro. Hydrobiologia 406: 21-31.

Gottstein S, Kerovec M. 2002. Atyaephyra desmaresti and Palaemonetes antennariurs (Crustacea, Decapoda, Caridea) in the delta of the Neretva river (Croatia). Biol Brat 57: 181-189.

Jabłońska A, Mamos T, Gruszka P, Szlauer-Łukaszewska A, Grabowski M. 2018a. First record and DNA barcodes of the aquarium shrimp, Neocaridina davidi, in Central Europe from thermally polluted River Oder canal, Poland. Knowl Manag Aquat Ecosyst 419: 14.

Jabłońska A, Mamos T, Zawal A, Grabowski M. 2018b. Morphological and molecular evidence for a new shrimp species, Atyaephyra vladoi sp. nov. (Decapoda, Atyidae) in the ancient Skadar Lake system, Balkan Peninsula-its evolutionary relationships and demographic history. Zool Anzr 275: 66-79.

Klotz W, Miesen FW, Hüllen S, Herder F. 2013. Two Asian freshwater shrimp species found in a thermally polluted stream system in North Rhine-Westphalia, Germany. Aquat Invasions 8: 333-339.

Kondrateva T, Nikonenkova T, Stepanova N. 2019. Using cilioplankton as an indicator of the ecological condition of aquatic ecosystems. Geosciences 9: 464.

Levitt-Barmats YA, Yanai Z, Cohen TM, Shenkar N. 2019. Lifehistory traits and ecological characteristics of the ornamental shrimp Neocaridina denticulata (De Haan, 1844), recently introduced into the freshwater systems of Israel. Aquat Invasions 14: 4 .

Liao CC, Shin JW, Chen LR, Huang LL, Lin WC. 2018. First molecular identification of Vorticella sp. from freshwater shrimps in Tainan, Taiwan. Int J Parasitol Parasites Wildl 7: 415-422.

Łabęcka AM, Domagała J. 2018. Continuous reproduction of Sinanodonta woodiana (Lea, 1824) females: an invasive mussel species in a female-biased population. Hydrobiologia 810: 57-76.

Maciaszek R. 2016. Selected species of freshwater shrimps parasites - biology, diagnostics and treatment. Engineering Thesis on Faculty of Animal Sciences, Warsaw University of Life Sciences (manuscript)

Maciaszek R, Kamaszewski M, Strużyński W, Łapa P. 2018. Epibionts of ornamental freshwater shrimps bred in Taiwan. Ann Warsaw Univ of Life Sci SGGW. Anim Sci 57: 133-142.

Maciaszek R, Jabłońska A, Prati S, Świderek W. 2020. First report of freshwater atyid shrimp, Caridina formosae (Decapoda: Caridea) as a host of ectosymbiotic branchiobdellidan, Holtodrilus truncatus (Annelida, Citellata). Knowl Manag Aquat Ecosyst 421: 33.

Matjašič J. 1990. Monography of the family Scutariellidae (Turbellaria, Temnocephalidea), Academia Scientiarum et Atrium Slovenica, Ljubljana, 45-91.

Mitsugi M, Suzuki H. 2018. Life history of an invasive freshwater shrimp Neocaridina davidi (Bouvier, 1904), (Decapoda: Caridea:
Atyidae) in the Tomoe River, the Boso Peninsula, eastern Japan. Crustac Res 47: 9-16.

Niwa N, Ohtaka A. 2006. Accidental introduction of symbionts with imported freshwater shrimps. In Koike F, Clout MN, Kawamichi M, De Poorter M, Iwatsuki K, eds. Assessment and control of biological invasion risks, Shoukadoh Book Sellers, Kyoto, Japan and IUCN, Gland, Switzerland, 182-186.

Ohtaka A, Gelder SR, Nishino M, Ikeda M, Toyama H, Cui YD, He XB, Wang HZ, Chen RB, Wang ZY. 2012. Distributions of two ectosymbionts, branchiobdellidans (Annelida: Clitellata) and scutariellids (Platyhelminthes: "Turbellaria": Temnocephalida), on atyid shrimp (Arthropoda: Crustacea) in southeast China. J Nat Hist 46: 1547-1556.

Ohtaka A, Gelder SR, Yamato S, Chen RT, Nishino M. 2015. Cohabitation of Ectosymbiotic Branchiobdellida (Annelida, Clitellata) and Scutarielloidae (Platyhelminthes, Rhabditophora, Temnocephalida) on Atyid Shrimps in Taiwan. Taiwan J Biodivers 17: 253-262.

Onuki K. 2021. The distribution of the invasive shrimp Neocaridina davidi (Decapoda: Caridea: Atyidae) in relation to environmental parameters in a stream at Kunitachi, Tokyo, Japan. Crustac Res 50: 33-39.

Patoka J, Bláha M, Devetter M, Rylková K, Čadková Z, Kalous L. 2016a. Aquarium hitchhikers: attached commensals imported with freshwater shrimps via the pet trade. Biol Invasions 18: 457-461.

Patoka J, Bláha M, Kalous L, Vrabec V, Buři M, Kouba A. 2016b. Potential pest transfer mediated by international ornamental plant trade. Sci Rep 6: 1-6.

Pešić V, Gadawski P, Gligorović B, Glöer P, Grabowski M, Kovács T, Murányi D, Płóciennik M, Sundić D. 2018. The diversity of the Zoobenthos communities of the Lake Skadar/Shkodra basin. In Pešić V, Karaman G, Kostianoy AG. eds. The Skadar/Shkodra Lake Environment. Cham: Springer, 255-293.

Šidagytė E, Razlutskij V, Alekhnovich A, Rybakovas A, Moroz M, Šniaukštaite V, Vaitonis G, Arbaiauskas K. 2017. Predatory diet and potential effects of Orconectes limosus on river macroinvertebrate assemblages of the southeastern Baltic Sea basin: implications for ecological assessment. Aquat Invasions 12: 523-540

Tomas AL, Sganga DE, López Greco LS. 2019. Effect of background color and shelters on female pigmentation in the ornamental red cherry shrimp Neocaridina davidi (Caridea, Atyidae). $J$ World Aquacult Soc 2019: 1-13

Twardochleb LA, Olden JD, Larson ER. 2013. A global meta-analysis of the ecological impacts of nonnative crayfish. Freshw Sci 32: $1367-1382$.

Vazquez ND, Delevati-Colpo K, Sganga DE, López-Greco LS. 2017. Density and gender segregation effects in the culture of the caridean ornamental red cherry shrimp Neocaridina davidi (Caridea: Atyidae). J Crustacean Biol 37: 367-373.

Weiperth A, Gábris V, Danyik T, Farkas A, Kuř́ková P, Kouba A, Patoka J. 2019. Occurrence of non-native red cherry shrimp in European temperate waterbodies: a case study from Hungary. Knowl Manag Aquat Ecosyst 420: 9.

Zhang Z, Yokota M, Strüssmann CA. 2019. Potential competitive impacts of the invasive Chinese mitten crab Eriocheir sinensis on native Japanese mitten crab Eriocheir japonica. Hydrobiologia 826: $411-420$.

Cite this article as: Maciaszek R, Świderek W, Kaliszewicz A, Karaban K, Szpakowski B. 2021. First report of Scutariella japonica (Matjašič, 1990), a temnocephalid epibiont from South-East Asia, found on introduced ornamental freshwater shrimp in European waters. Knowl. Manag. Aquat. Ecosyst., 422, 19. 